DOI: 10.20472/IAC.2017.33.056

SUNG-UK PARK

KISTI, Korea, Republic of

\title{
THE 4TH INDUSTRIAL REVOLUTION AND R\&D POLICY
}

\begin{abstract}
:
In this 4th Industrial Revolution, we are facing a range of new technologies that combine the physical, digital and biological worlds. These new technologies will impact all disciplines, economics and industries, and even challenge our ideas about what it means to be human. These technologies have great potential to continue to connect billions more people to the web, drastically improve the efficiency of business and organizations and help regenerate the natural environment through better asset management, potentially even undoing all the damage previous industrial revolution have caused. (Bernard Marr, 2016). And, More than $70 \%$ of South Koreans fear that the advent of the 4th industrial revolution will threaten their jobs.

In this paper I studied about 4th Industrial Revolution. Especially I surveyed about between Industrial Revolution and R\&D policy of Science \& Technology.
\end{abstract}

\section{Keywords:}

4th Industrial Revolution; R\&D; S\&T; Budget; Policy

JEL Classification: L88, F68, L60 


\section{Definition}

The $4^{\text {th }}$ Industrial Revolution is the fourth major industrial era since the initial Industrial Revolution of the $18^{\text {th }}$ century. The $4^{\text {th }}$ Industrial Revolution can be described as a range of new technologies that are fusing the physical, digital and biological worlds, and impacting all disciplines, economies and industries, Klaus Schwab has associated with the "second machine age" in terms of the effects of digitization and Al on the economy, but added a broader role for advances in biological technologies. Schwab sees as parts of this revolution "emerging technology breakthroughs" in fields such as artificial intelligence, robotics, the internet of Things, autonomous vehicles, 3D printing, quantum computing and nanotechnology(Wikipedia, 2017)

According to WEF(2016), The First Industrial Revolution used water and steam power to mechanize production. The Second used electric power to create mass production. The Third used electronics and information technology to automate production. Now a Fourth Industrial Revolution is building on the Third, the digital revolution that has been occurring since the middle of the last century. It is characterized by a fusion of technologies that is blurring the lines between the physical, digital and biological spheres.

Figure 1. Trend of Industrial Revolution

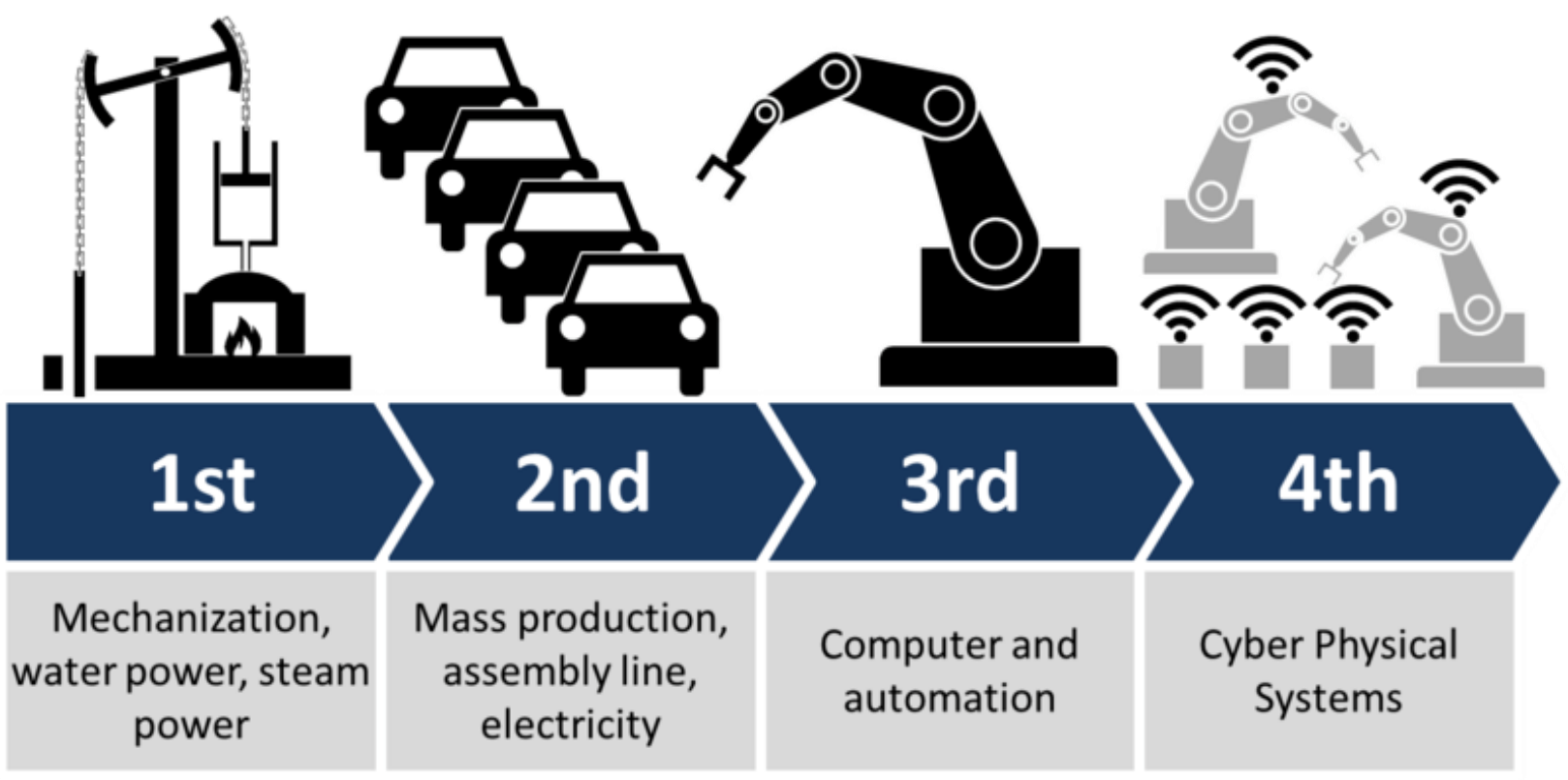

Source: Inhapress (2017)

\section{Preparing for the $\mathbf{4}^{\text {th }}$ Industrial Revolution}

According to Inhapress(2017), in the U.S., IBM, Amazon, Microsoft, and Google are representative. IBM developed Watson, an artificial intelligence, and it won the 2012 Jeopardy Quiz show, beating its human opponents. Watson was also used for medical 
purposes as it was able to store up to 15 million pages of medical information, including 300 medical journals and 200 medical textbooks. One only had to enter a patients test results for Watson to offer a diagnosis: Watson had a diagnostic accuracy of $98 \%$ for colorectal cancer, $94 \%$ for pancreatic cancer, and $100 \%$ for cervical cancer. Watson's real strength though was its speed and accuracy. It could read and analyze 70,000 papers in a month and identified six proteins that affected the anticancer gene. Amazon, the world's largest Internet on-line vendor, is also profiting from robot technology due to its purchase of the robotics company KIVA Systems, in 2012, for $\$ 750$ million (850 billion won) to develop robots for logistical automation. Amazon has already developed a robot that can classify and organize products faster, and with less errors, than a human. The company's logistical costs are expected to drop from $\$ 900$ million to $\$ 450$ million. Microsoft launched an AR (augmented reality - your immediate environment is scanned to allow virtual images to be superimposed on the real world) device in the form of glasses called Hololens. For example, whilst watching a football match on TV, information about a player will appear on the lenses of the glasses. Indeed, the practical applications of Hololens are vast - fields such as architecture, civil engineering, manufacturing, gaming, and national defense could all benefit from this tech. Hololens hit the American market in August 2016, for the price of $\$ 3000$, and thousands have been sold as of February 2017.. Where Google is concerned autonomous car (self-driving cars) development has been a major focus. From 2009 to 2015 , after some 2.8 million kilometers of test driving, only 14 accidents have occurred. None of these accidents, however, was due to a failure of a car's automated systems. Google is planning to make driverless cars available to the public by 2020 .

In the case of Japan, Sony has been busy ushering in the fourth industrial revolution, with the development of Pepper and Playstation VR (virtual reality). Pepper is a household humanoid robot released by Sony in 2015. Pepper's most remarkable feature is its capacity to recognize human emotions. It has four microphones, two cameras, a 3D sensor, touch sensor, laser sensor, sound sensor, and gyroscope to gather and respond to situational information. For instance, if you ask for a handshake, Pepper sticks out its hand and responds according to your tone and facial expression. If you force a smile, Pepper says, "Your eyes are not smiling." Despite a cost of $\$ 2000,7000$ Peppers have already been sold. Sony's Playstation VR is a headset that connects to the PlayStation 4. The headset cuts out an view of the outside an instead renders the environment of a game, which gives gamers the sense of being immersed in the game's world - hence, virtual reality. Movies can also be viewed using the headset. Playstation VR was released in October 2016 and sold 915,000 units in its first five months on sale.

In the case of South Korea, According to The Korea Times(2017), South Korea has been already moving to incorporate the fourth industrial revolution into the economy. Last year, the government launched the fourth-revolution strategy committee comprised of senior government policymakers and business people. The committee aims to spearhead policy-making on cloud computing, loT, production 
automation, management and governance system, and the transformation of economy, society and education. Moon's economic policies largely boil down to generating more jobs, which he believes is the most important for sustainable economic growth. The new chief executive claimed earlier that his government will increase investment in 10 major areas that include the fourth industrial revolution and the social services sector, which can stimulate more hiring. Moon said earlier such investments would include creating 810,000 new jobs in the public sector during his five-year presidency, which he said would prompt the private sector to create 500,000 new jobs per year.

Figure 2. Policy of Industrial Revolution

\begin{tabular}{ll}
$\begin{array}{l}\text { Strong brand Industrie 4.0 } \\
\text { Strengths in the production sector }\end{array}$ & $\begin{array}{l}\text { High level of training \& qualification } \\
\text { Excellent international reputation }\end{array}$ \\
$\begin{array}{ll}\text { Strong focus on new business models } \\
\text { IT-start-ups in Industrie 4.0 }\end{array}$ & $\begin{array}{l}\text { Large domestic market } \\
\text { Driven by private organizations (e.g. IIC) }\end{array}$ \\
$\begin{array}{ll}\text { High-tech operating companies \& } \\
\text { low-tech SME }\end{array}$ & $\begin{array}{l}\text { Ambitious government programs (China 2025) } \\
\text { Fragile legal framework }\end{array}$ \\
$\begin{array}{l}\text { Knominance of "Chaebols" } \\
\text { Strong production sector } \\
\text { Complex standardization landscape }\end{array}$ & $\begin{array}{l}\text { Focus on production efficiency } \\
\text { Strengths in IT-infrastructure }\end{array}$ \\
$\begin{array}{l}\text { Focus on reindustrialization } \\
\text { Strengths in smart services }\end{array}$ & $\begin{array}{l}\text { Focus on new business models } \\
\text { Strengths in robotic \& work science }\end{array}$ \\
\hline
\end{tabular}

Source. Andreas Heindl (2017)

\section{Trend of R\&D}

According to Wikipedia(2017), Research and Development(R\&D) also known in Europe as research and technological development is activities in connection with corporate or government innovation. Research and development constitutes the first stage of development of a potential new service or product.

R\&D activities differ from institution to institution, with two primary models of an R\&D department either staffed by engineers and tasked with directly developing new products, or staffed with industrial scientists and tasked with applied research in scientific or technological fields, which may facilitate future product development. R\&D differs from the vast majority of corporate activities in that it is not intended to yield immediate profit, and generally carries greater risk and an uncertain return on investment. However R\&D is crucial for acquiring lager shares of the market through the marketization of new products. 
Figure 3. Cycle of R\&D

\section{Scale Up and Study Effectiveness}

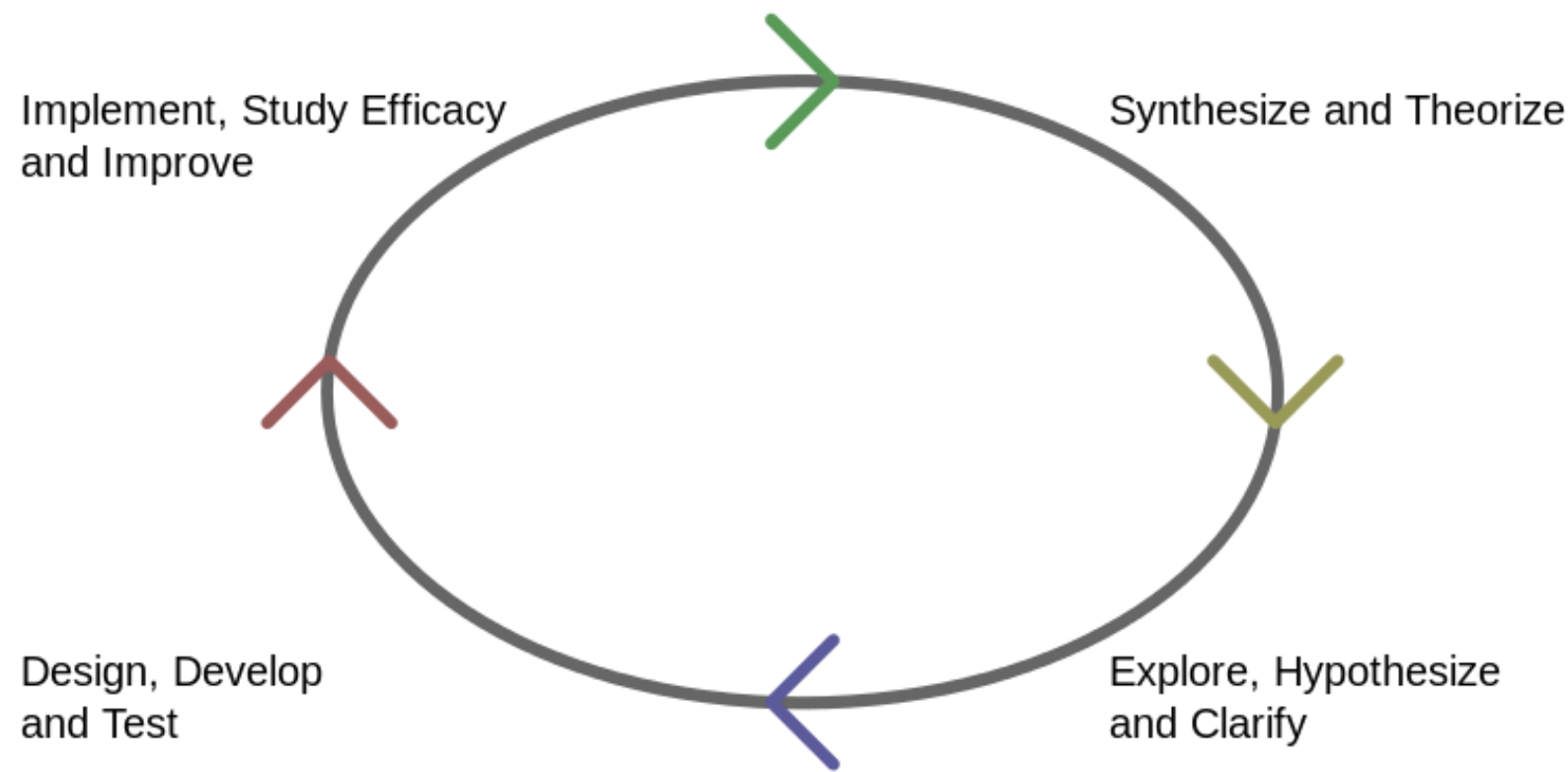

Cycle of Research and Development

Source: Wikipedia(2017).

According to D.Nobelius(2003), The perspective on R\&D processes has been different throughout the years, since the structure and prerequisites of the economy have changed and so has the presumption of best practice. One attempt at describing the last 50 years of evolution within the R\&D field is shown in Table 1. Worth noticing is that these five models of R\&D generations, though presented on a time scale, hold components or ideas still valid and sought for by many companies, and hence do not represent a map of where companies today are to be placed. Throughout these periods, different industries or companies have functioned as role models or drivers of best practice, a phenomenon that can also be recognized from research results. 
Table 1. Description of five generation of R\&D process

\begin{tabular}{lll}
\hline R\&D Generations & \multicolumn{1}{c}{ Context } & \multicolumn{1}{c}{ Process Characteristics } \\
\hline First generation & $\begin{array}{c}\text { Black hole demand } \\
\text { (1950 to mid- 1960s) }\end{array}$ & $\begin{array}{l}\text { R\&D as ivory tower, technology-push oriented, } \\
\text { seen as an overhead cost, having little or no } \\
\text { interaction with the rest of the company or overall } \\
\text { strategy. Focus on scientific breakthroughs. }\end{array}$ \\
\hline Second generation & $\begin{array}{c}\text { Market shares battle } \\
\text { (mid-1960s to } \\
\text { early 1970s) }\end{array}$ & $\begin{array}{l}\text { R\&D as business, market-pull oriented, and } \\
\text { strategy-driven from the business side, all under } \\
\text { the umbrella of project management and the } \\
\text { internal customer concept. }\end{array}$ \\
\hline Third generation & $\begin{array}{c}\text { Rationalization efforts } \\
\text { (mid-1970s to } \\
\text { mid-1980s) }\end{array}$ & $\begin{array}{l}\text { R\&D as portfolio, moving away from individual } \\
\text { projects view, and with linkages to both business } \\
\text { and corporate strategies. Risk-reward and similar } \\
\text { methods guide the overall investments. }\end{array}$ \\
\hline Fourth generation & $\begin{array}{l}\text { Time-based struggle } \\
\text { (early 1980s to } \\
\text { mid-1990s) }\end{array}$ & $\begin{array}{l}\text { R\&D as integrative activity, learning from and } \\
\text { with customers, moving away from a product } \\
\text { focus to a total concept focus, where activities } \\
\text { are conducted in parallel by cross-functional } \\
\text { teams. }\end{array}$ \\
\hline Fifth generation & $\begin{array}{l}\text { Systems integration } \\
\text { (mid-1990s onward) }\end{array}$ & $\begin{array}{l}\text { R\&D as network, focusing on collaboration within } \\
\text { a wider system - involving competitors, } \\
\text { product development speed is imperative, } \\
\text { separating R from D. }\end{array}$ \\
\hline
\end{tabular}

Source: D.Nobelius(2003)

\section{Conclusions}

As automation increases, computers and machines will replace workers across a vast spectrum of industries, from drivers to accountants and estate agents to insurance agents. By one estimate, as many as $47 \%$ of U.S jobs are at risk from automation(Bernard Marr, 2016).

According to BusinessKorea(2017), In regard to research and development (R\&D) in the scientific technology and information and communications technology (ICT) areas, the Ministry of Science, ICT and Future Planning (MSIP) will significantly increase the proportion of free contests that allow researchers to choose a research topic his own and submit an application this year. It is also expanding investment in the software sector, the core foundation of the fourth Industrial Revolution, including artificial intelligence (AI). 
The MSIP confirmed and released the "2017 comprehensive R\&D Implementation plan for scientific technology and ICT sector" worth a total of 4.13 trillion won (US $\$ 3.43$ billion) on January 1 . The plan excludes research and operating costs of the National Research Council of Science \& Technology (NST) and the NST-funded research institutes among the MSIP's total R\&D budgets of 6.77 trillion won (US $\$ 5.62$ billion), and includes detailed operation plans for the scientific technology sector of 3.14 trillion won (US\$2.61 billion) and the ICT sector of 989.6 billion won (US $\$ 821.24$ million).

The heart of the MSIP's R\&D plan this year is to proactively cope with the fourth Industrial Revolution era through creative R\&D and strategically focus on the investment in technologies that can prepare for the fourth industrial revolution.

Korea's labor market is least likely to be affected by the $4^{\text {th }}$ industrial revolution among OECD member countries, thanks to highly educated workers and pre-emptive investments in automation, according to state-run think tanks.(Kang Seung-woo, 2017)

\section{References}

Andreas Heindl, Industrie 4.0 - Features, Potentials, and Challenges, Conference, Smart Industry 2017, 23 May 2017.

Bernard Marr(2016), Why Everyone Must Get Ready For The $4^{\text {th }}$ Industrial Revolution, Forbes.

BusinessKorea(2017), S.Korea's Gov't to Spend $\$ 3.5$ in R\&D to Prepare for $4^{\text {th }}$ Industrial Revolution, 2 Jan 2017.

D.Nobelius(2003), Towards the sixth generation of R\&D management, International Journal of Project Management, 27 Oct 2003.

Inhapress, Preparing for the Fourth Industrial Revolution, 16 June 2017.

The Korea Times, $4^{\text {th }}$ Industrial Revolution key agenda for Moon's economic policy, 19 July 2017.

Kang Seung-woo(2017), Korea well-prepared for $4^{\text {th }}$ Industrial Revolution, The KoreaTimes.

World Economic Forum(2016), The Fourth Industrial Revolution: what it means, how to respond, 14 Jan 2016.

Wikipedia, Fourth Industrial Revolution, https://en.wikipedia.org/wiki/Fourth Industrial Revolution, July 2017.

Wikipedia, Research and development, https://en.wikipedia.org/wiki/Research and development, July 2017. 